\title{
Tingkat Kepuasan Pelayanan Pasien Rawat Jalan BOJS di Instalasi Farmasi Puskesmas Tlogosadang Kabupaten Lamongan
}

(Service Satisfication Level of BPJS Outpatients at the Pharmacy Installation of Tlogosadang Public Health Center, Lamongan Regency)

\author{
Yoga Dwi Setya Laksana ${ }^{1 *}$, Pemta Tiadeka ${ }^{2}$, Abdur Rivai $^{3}$ \\ Puskesmas Tlogosadang Lamongan ${ }^{1}$,Universitas Muhammadiyah Gresik ${ }^{2.3}$ \\ Jalan raya Dagan Tlogosadang Lamongan Jawa Timur Indonesia $62264^{1}$ \\ Email : yogasetya1508@gmail.com*
}

Info artikel:
Diterima:
17/09/21
Direview:
16/09/21
Diterbitkan:.
24/10/21

Info artikel:

Diterima:

$24 / 10 / 21$

\begin{abstract}
Abstrak
Kepuasan pasien berkaitan erat dengan mutu pelayanan. Mutu pelayanan yang optimal akan memberikan pengalaman yang positif kepada pasien serta kunjungan pasien juga diharapkan meningkat. Salah satu strategi untuk menambah nilai pelayanan adalah dengan BPJS. Berdasarkan studi pendahuluan yang dilakukan di Puskesmas Tlogosadang Lamongan, teramati adanya peningkatan jumlah pasien umum dan BPJS di Puskesmas Tlogosadang. Selain itu, hasil wawancara awal dengan 20 pasien yang ada di Puskesmas Tlogosadang menunjukkan bahwa 60\% pasien Instalasi Farmasi Rawat Jalan menyatakan tidak puas terhadap pelayanan Puskesmas. Oleh karena itu, penelitian ini dilakukan untuk mengkaji tingkat kepuasan pelayanan pasien rawat jalan BPJS di Instalasi Farmasi Rawat Jalan Puskesmas Tlogosadang. Penelitian ini merupakan jenis penelitian deskriptif kualitatif dengan teknik accidental sampling. Hasil penelitian ini menunjukkan bahwa sebanyak 70\% pasien tergolong di dalam kategori "merasa puas" untuk dua dimensi berikut ini, yaitu kehandalan dan ketanggapan. Selain itu sebanyak 60\% pasien tergolong di dalam kategori "merasa puas" untuk dimensi empati. Sebaliknya sebanyak $66 \%$ dan $56 \%$ pasien berturut-turut tergolong di dalam kategori "kurang puas" untuk penilaian terhadap dimensi kemampuan dan bukti fisik. Secara keseluruhan tingkat kepuasan pasien terhadap pelayanan di instalasi farmasi puskesmas Tlogosadang yang tergolong di dalam kategori "merasa puas" adalah 66,27\%.
\end{abstract}

Kata kunci : Tingkat kepuasan, pasien BPJS, rawat jalan

\begin{abstract}
Patient satisfaction is closely related to service quality. The optimum quality will provide positive experience for patients and hence, the number of visiting patients is expected to increase. A strategy to improve the value of service is BPJS. Based on a preliminary study conducted at the Tlogosadang Public Health Center, Lamongan, the increased number of general and BPJS patients at the Tlogosadang Public Health Center was observed. In addition, the result of initial interview with 20 patients at the Tlogosadang Public Health Center showed the dissatisfaction of $60 \%$ of the Pharmacy Installation outpatients toward the services provided by the public health community. Therefore, this study aimed to review the level of service satisfaction of BPJS outpatients at the Pharmacy Installation of Tlogosadang Public Health Center. This was a qualitative descriptive research type with accidental sampling technique. This research is a type of qualitative descriptive research with accidental sampling technique. This study showed that $70 \%$ of patients was categorized in "satisfactory" group for two following dimensions, namely reliability and responsiveness. In addition, $60 \%$ of patients was classified in "satisfactory" group for empathy dimension assessment. In contrast, $66 \%$ and 56\% of patients were included in the "less satisfactory" group for the evaluation of assurance and tangibility dimensions, respectively. Overall the satisfaction level of patients toward the services at the Pharmacy Installation of Tlogosadang Public Health Center that was classified in "satisfactory" group was $66.27 \%$
\end{abstract}

Keyword : Level Satisfication, BPJS Patient, outpatient 


\section{PENDAHULUAN}

Kepuasan pasien merupakan indikator utama dari standar ukuran mutu pelayanan di suatu Puskesmas. Kepuasan pasien yang rendah akan berdampak pada jumlah kunjungan di suatu Puskesmas. Pasien yang berkunjung diharapkan selalu meningkat seiring dengan berjalannya waktu, sehingga tuntutan terhadap mutu pelayanan akan senantiasa meningkat, termasuk dari peserta jaminan kesehatan.

Pengalaman atas pelayanan kesehatan pada periode sebelumnya merupakan suatu hal yang penting untuk bahan evaluasi bagi perbaikan pelayanan kesehatan di masa yang akan datang. Kepuasan atas pelayanan juga akan mempengaruhi harapan pasien untuk memperoleh pelayanan yang sama. Pelayanan harus diberikan sesuai kebutuhan pasien dengan tepat, ramah, dan cepat (Sunarto, 2011). Pelayanan kefarmasian secara terbatas sebagaimana dimaksud, meliputi pengelolaan sediaan farmasi dan bahan medis habis bakai, pelayanan resep berupa peracikan obat, penyerahan obat, dan pemberian informasi obat (Menkes RI, 2016).

Jaminan kesehatan adalah jaminan berupa perlindungan kesehatan agar peserta memperoleh manfaat pemeliharaan kesehatan dan perlindungan dalam memenuhi kebutuhan dasar kesehatan yang diberikan kepada setiap orang yang telah membayar iuran jaminan kesehatan atau iuran jaminan kesehatannya dibayar oleh Pemerintah Pusat ataupun Pemerintah Daerah. Salah satu tujuan dari jaminan kesehatan masyarakat adalah mendorong peningkatan pelayanan kesehatan yang standar bagi peserta, tidak berlebihan sehingga mutu dan biaya pelayanan kesehatan tetap dapat terkendali.

Pada saat ini, terjadi peningkatan kunjungan pasien peserta BPJS di Puskesmas Tlogosadang. Berdasarkan studi pendahuluan yang dilakukan di Puskesmas tersebut, jumlah pasien umum dan pasien peserta BPJS di Puskesmas Tlogosadang mengalami peningkatan selama 3 bulan, yaitu Maret hingga Mei 2020. Jumlah kunjungan pasien rawat jalan peserta BPJS di Puskesmas Tlogosadang pada bulan Maret, April, dan Mei 2020 berturut-turut sebanyak 632 orang, 355 orang, dan 432 orang. Dengan demikian jumlah kunjungan pasien rawat jalan peserta BPJS selama 3 bulan tersebut adalah 1419 orang.

Hasil wawancara awal dengan 20 pasien di Puskesmas Tlogosadang memberikan gambaran awal bahwa $60 \%$ pasien Instalasi Farmasi Rawat Jalan menyatakan tidak puas terhadap pelayanan Puskesmas. Oleh karena itu, penting untuk dilakukan studi tentang tingkat kepuasan pelayanan pasien rawat jalan BPJS di Instalasi Farmasi Rawat Jalan Puskesmas Tlogosadang.

\section{II.METODE PENELITIAN}

Penelitian ini dilakukan di Instalasi Farmasi Puskesmas Tlogosadang Kabupaten Lamongan. Rancangan penelitian ini adalah penelitian deskriptif kualitatif. Teknik pengambilan sampel dilakukan secara accidental sampling. Variabel penelitian pada penelitian ini adalah variabel tunggal, yaitu 
kepuasan pelayanan, dengan sub-variabel 1) reliability, 2) responsiveness, 3) assurance, 4) tangibility, dan 5) empati. Pengumpulan data dilakukan dengan menggunakan skala Likert 4 tingkatan (Notoatmojo, 2016).

Populasi pada penelitian ini adalah seluruh pasien rawat jalan BPJS yang menebus resep di Instalasi Farmasi Puskesmas Tlogosadang. Sampel penelitian ini adalah sebagian pasien rawat jalan BPJS yang menebus resep di Instalasi Farmasi Puskesmas Tlogosadang pada bulan Juni 2020, yaitu sebanyak 83 orang.

Data lembar kuesioner yang diperoleh kemudian diolah dan hasil dari lembar kuesioner dianalisis dengan menghitung jumlah dari masing-masing butir kuesioner pada lembar kuesioner tersebut. Selanjutnya, dihitung skor rata-rata untuk kepuasan pasien pada masing-masing dimensi, yang terdiri dari reliability, responsiveness, assurance, tangibility, dan empati, dari pertanyaan pada kuesioner dengan menggunakan rumus berikut ini: (Sugiyono, 2017)

$$
T K P=\frac{\text { Skor perolehan }}{\text { Skor maksimal }} \times 100 \%
$$

Skor 1 merupakan skor paling rendah hingga skor 4 merupakan skor paling tinggi. Penggolongan kategori tingkat kepuasan pasien ditunjukkan pada Tabel 1 (Novaryatiin dkk., 2018).

Instrumen penelitian yang digunakan pada penelitian ini adalah sebagai berikut:

\begin{tabular}{|l|l|l|l|l|l|}
\hline No. & Pertanyaan & 1 & 2 & 3 & 4 \\
\hline Reliability (kehandalan) \\
\hline 1. & Apakah Bapak/Ibu/ & & & & \\
\hline
\end{tabular}

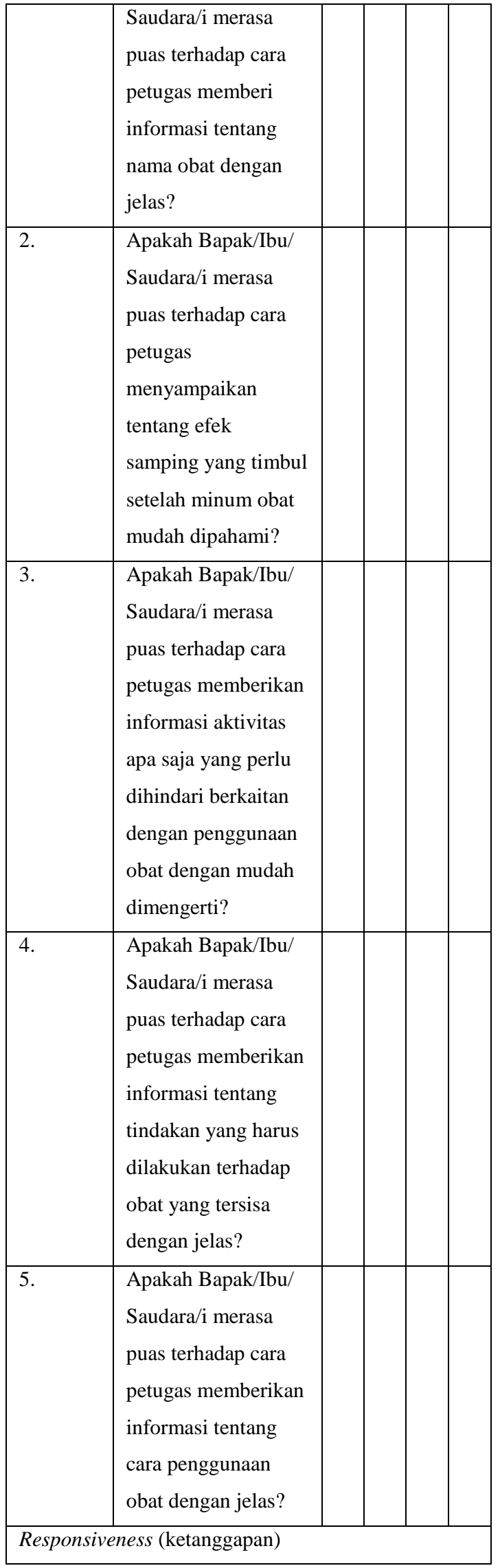




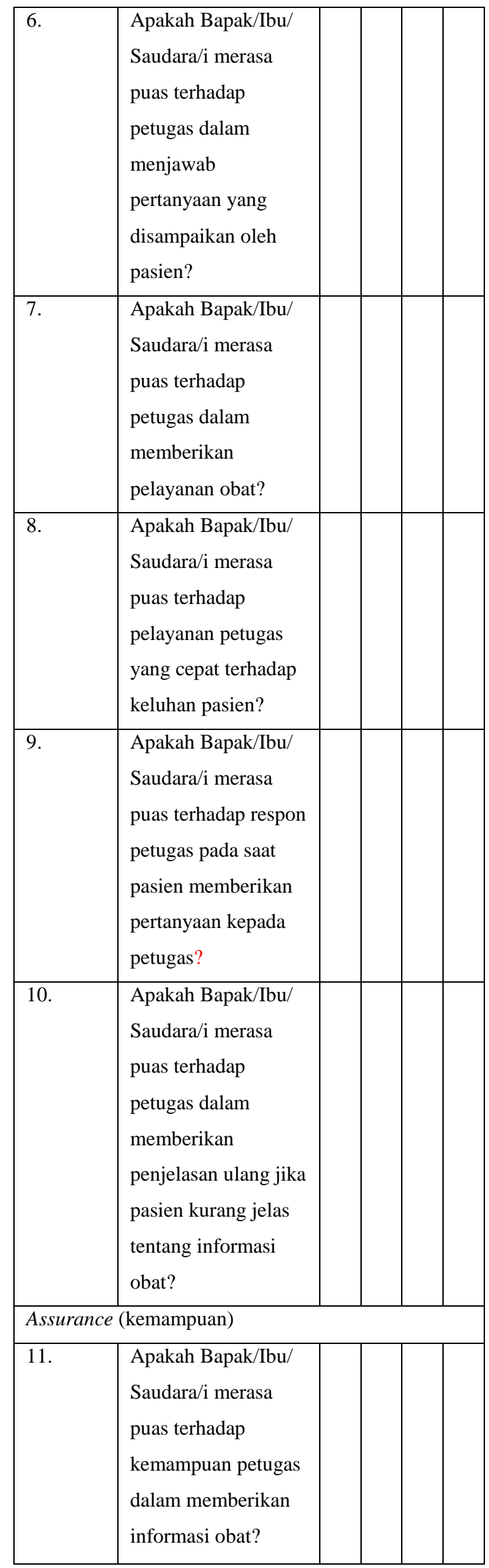

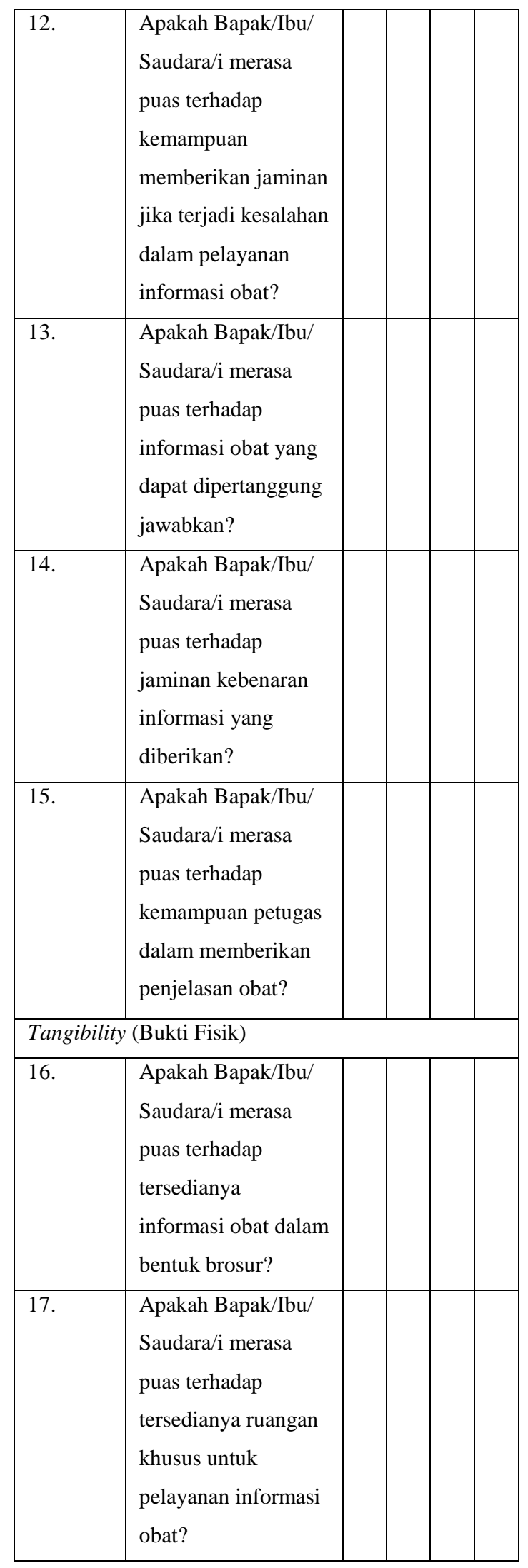




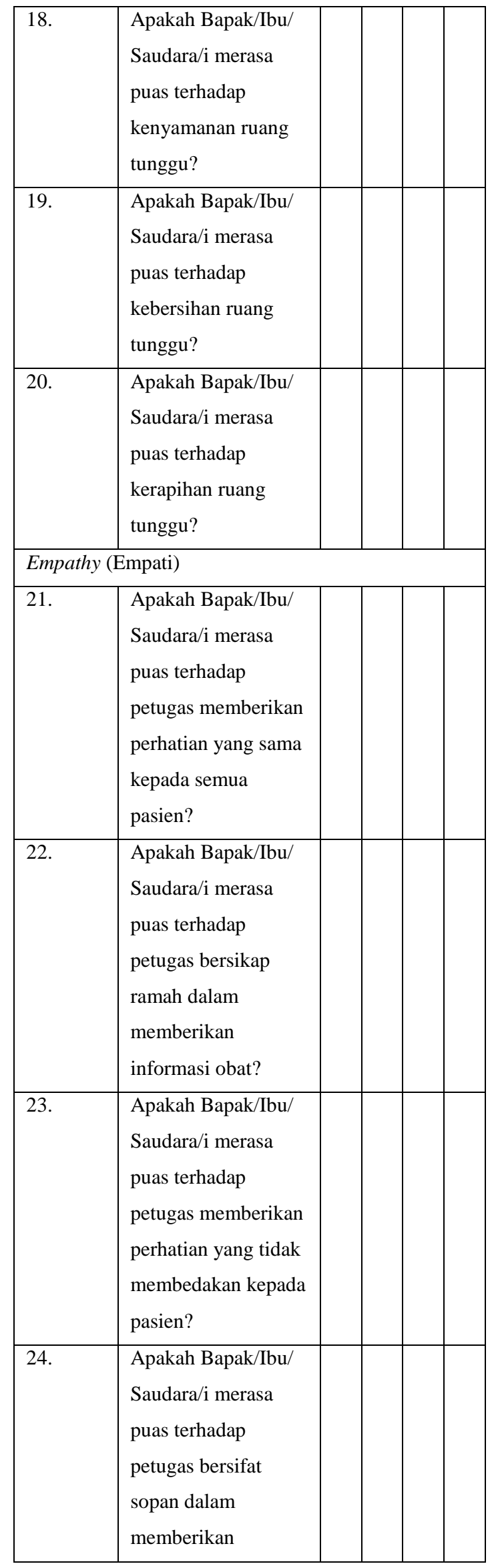

\begin{tabular}{|l|l|l|l|l|l|}
\hline & informasi obat? & & & & \\
\hline 25. & $\begin{array}{l}\text { Apakah Bapak/Ibu/ } \\
\text { Saudara/i merasa } \\
\text { puas terhadap } \\
\text { kesungguhan } \\
\text { petugas dalam } \\
\text { memberikan } \\
\text { informasi obat? }\end{array}$ & & & & \\
\hline
\end{tabular}

Tabel 1. Kategori Tingkat Kepuasan

\begin{tabular}{ll}
\hline \multicolumn{1}{c}{$\begin{array}{c}\text { Skor } \\
\text { Rata- rata }\end{array}$} & \multicolumn{1}{c}{ Kriteria } \\
\hline $0-25$ & Tidak Puas \\
\hline $26-50$ & Kurang Puas \\
\hline $51-75$ & Puas \\
\hline $76-100$ & Sangat Puas \\
\hline
\end{tabular}

Keterangan:

1. Tidak puas

2. Kurang puas

3. Puas

4. Sangat puas

\section{HASIL DAN PEMBAHASAN}

Hasil identifikasi karakteristik dari 83 responden ditunjukkan pada Tabel 2. Berdasarkan hasil pengamatan, sebagian responden berjenis kelamin perempuan, yaitu $53 \%$, dengan tingkat pendidikan tertinggi SMA sebesar 54\%. Menurut Jacobalis dalam Eninurkhayatun, dkk. (2017), jenis kelamin mempengaruhi persepsi konsumen terhadap kualitas pelayanan. Selain itu, jenis pekerjaan dari responden yang terbanyak adalah swasta atau wiraswasta, dan frekuensi kunjungan tertinggi ke puskemas sebanyak lebih dari 5 kali. Menurut Kotler (2004), kepuasan konsumen yang positif terhadap kualitas pelayanan secara keseluruhan mempengaruhi minat penggunaan jasa 
yang sama oleh konsumen tersebut. Selanjutnya, tingkat pendidikan juga akan berpengaruh pada tingkat kesadaran akan pentingnya kesehatan. Semakin tinggi tingkat pendidikan seseorang, maka semakin tinggi pula tingkat pemahamannya akan pentingnya kesehatan (Ndjurumbaha, 2015).

\section{Tabel 2. Data Karaekteristik Responden}

\begin{tabular}{|c|c|c|}
\hline \multicolumn{3}{|c|}{ Karakteristik Umum Responden } \\
\hline & $\begin{array}{c}\text { Jumlah } \\
\text { Responden }\end{array}$ & $\begin{array}{c}\text { Presentase } \\
\text { Responden (\%) }\end{array}$ \\
\hline \multicolumn{3}{|l|}{ Jenis Kelamin } \\
\hline $\begin{array}{ll}1 & \text { Laki - laki }\end{array}$ & 39 & 47 \\
\hline 2. Perempuan & 44 & 53 \\
\hline \multicolumn{3}{|l|}{ Tingkat pendidikan } \\
\hline $1 \quad \mathrm{SD}$ & 0 & 0 \\
\hline $2 \quad$ SMP & 13 & 16 \\
\hline $3 \quad$ SMA & 54 & 65 \\
\hline $4 \quad$ Diploma & 5 & 6 \\
\hline $\begin{array}{ll}5 & \begin{array}{l}\text { Perguruan } \\
\text { Tinggi }\end{array}\end{array}$ & 11 & 13 \\
\hline \multicolumn{3}{|l|}{ Jenis Pekerjaan } \\
\hline $1 \quad$ PNS & 11 & 13 \\
\hline $\begin{array}{ll}2 & \text { Swasta / } \\
& \text { Wiraswasta }\end{array}$ & 42 & 52 \\
\hline $3 \begin{array}{l}\text { Lainnya ( ibu } \\
\text { rumah tangga } \\
\text { dan nelayan) }\end{array}$ & 30 & 35 \\
\hline \multicolumn{3}{|l|}{ Jumlah Kunjungan } \\
\hline $\begin{array}{ll}1 & \begin{array}{c}\text { Baru } \\
\text { pertama kali }\end{array}\end{array}$ & 5 & 6 \\
\hline $2-5$ kali & 21 & 25 \\
\hline $\begin{array}{l}\text { Lebih dari } 5 \\
\text { kali }\end{array}$ & 57 & 69 \\
\hline Jumlah & 83 & 100 \\
\hline
\end{tabular}

Data Hasil Pengukuran Tingkat Kepuasan Pasien di Instalasi Farmasi Puskesmas Tlogosadang

Kepuasan pasien terhadap pelayanan kefarmasian di instalasi farmasi Puskesmas Tlogosadang dievaluasi melalui 5 variabel, yaitu kehandalan, ketanggapan, kemampuan, bukti fisik, dan empati.

\section{Dimensi Kehandalan atau Reliability}

Hasil pengukuran terhadap tingkat kepuasan pasien untuk dimensi reliability (Tabel 3) menunjukkan bahwa sebanyak 58 orang atau $70 \%$ pasien merasa puas, sedangkan jumlah pasien yang merasa sangat puas sebanyak 25 orang atau 30\%. Hal ini dikarenakan petugas telah memberikan informasi mengenai obat secara lengkap dengan bahasa yang mudah dipahami oleh pasien yang sebagian besar memiliki latar belakang pendidikan SMA. Adapun informasi yang diberikan meliputi nama obat, aturan minum obat, cara pemakaian obat, kegunaan obat, dan cara penyimpanan obat.

Namun demikian, apabila ditinjau dari masingmasing sub-variabel pada dimensi kehandalan (no. 1-5), diperoleh nilai rata-rata kepuasan pasien sebesar $76,45 \%$ yang termasuk dalam kategori "sangat puas". Hasil pengukuran ini ditunjukkan pada Gambar 1, yang menunjukkan bahwa pelayanan kefarmasian di Puskesmas Tlgogosadang sudah baik. Hal ini teramati pada kepuasan pasien yang tinggi terhadap variabel ketepatan dan kecepatan petugas dalam memberikan informasi obat, yang meliputi nama, efek samping, bahasa yang lugas, serta penggunaan dan penanganan obat sisa. 
Tabel 3. Tingkat Kepuasan Pasien terhadap Dimensi Kehandalan Ditinjau dari Jumlah Pasien.

\begin{tabular}{clcc}
\hline No & $\begin{array}{c}\text { Tingkat } \\
\text { Kepuasan }\end{array}$ & $\begin{array}{c}\text { Jumlah } \\
\text { Responden }\end{array}$ & $\begin{array}{c}\text { Presentase } \\
\text { Responden } \\
(\boldsymbol{\%})\end{array}$ \\
\hline 1 & Sangat Puas & 20 & 24 \\
2 & Puas & 58 & 70 \\
3 & Kurang Puas & 5 & 6 \\
4 & Tidak Puas & 0 & 0 \\
\hline & Jumlah & 83 & 100
\end{tabular}

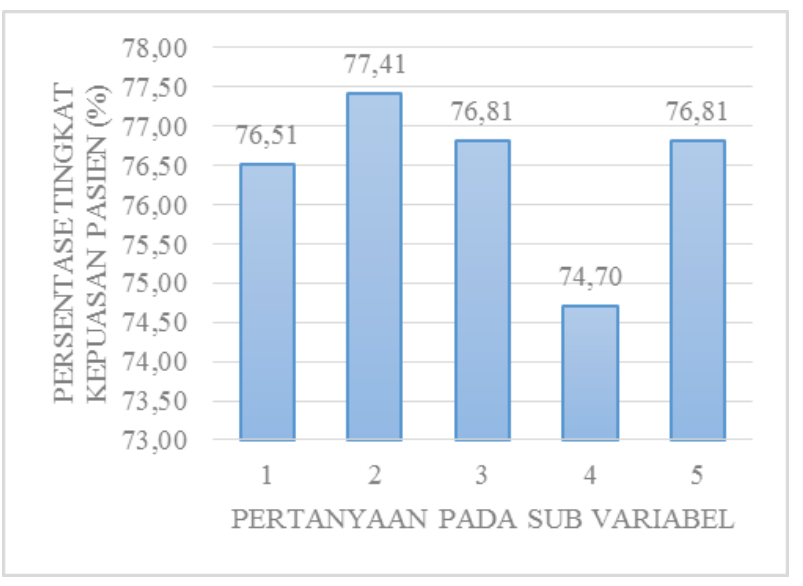

Gambar 1. Tingkat kepuasan pasien terhadap dimensi kehandalan Berdasarkan Sub Variabel

\section{Dimensi Ketanggapan / Responsiveness}

Menurut Sondari (2015), kepuasan pelayanan pada dimensi responsiveness atau ketanggapan adalah keinginan untuk membantu dan menyediakan jasa yang sangat dibutuhkan oleh konsumen. Tabel 4 menunjukkan bahwa jumlah pasien yang merasa kurang puas sebanyak 5 orang atau $6 \%$, sedangkan jumlah pasien yang merasa puas dan sangat puas berturut-turut sebesar 58 orang $(70 \%)$ dan 20 orang (24\%). Hal ini berkaitan dengan ketanggapan petugas dalam menjawab pertayaan maupun keluhan yang diajukan oleh pasien, memberikan pelayanan informasi obat yang baik, serta ketanggapan petugas dalam memberikan penjelasan ulang kepada pasien yang merasa kurang jelas tentang informasi obat, kegunaan obat, dan cara penyimpanan obat.

Tabel 4. Tingkat Kepuasan Pasien terhadap Dimensi Ketanggapan Ditinjau dari Jumlah Pasien.

\begin{tabular}{clcc}
\hline No & $\begin{array}{l}\text { Tingkat } \\
\text { Kepuasan }\end{array}$ & $\begin{array}{c}\text { Jumlah } \\
\text { Responden }\end{array}$ & $\begin{array}{c}\text { Presentase } \\
\text { Responden } \\
(\%)\end{array}$ \\
\hline 1 & Sangat Puas & 25 & 30 \\
2 & Puas & 58 & 70 \\
3 & Kurang Puas & 0 & 0 \\
4 & Tidak Puas & 0 & 0 \\
\hline & Jumlah & 83 & 100 \\
\hline
\end{tabular}

Selain itu, tingkat kepuasan terhadap masingmasing sub-variabel pada dimensi ketanggapan menunjukkan bahwa sebagian besar pasien yang berkunjung ke Puskesmas Tlogosadang menyatakan puas terhadap pelayanan kefarmasiannya dengan nilai rata-rata yang diperoleh sebesar 74,28\%. Hal ini didukung oleh keluangan waktu dari petugas untuk mau menanggapi permintaan pasien dengan cepat dan ketersediaan petugas dalam membantu pasien. Petugas dengan cepat memberikan respon terhadap pertanyaan pasien dan tanggap dalam memberikan penjelasan ulang apabila pasien merasa kurang jelas terhadap informasi obat yang telah disampaikan sebelumnya oleh petugas. Menururt Eninurkhayatun, dkk. (2017), kecepatan dalam penanganan keluhan menjadi hal yang sangat penting dalam memastikan kepuasan konsumen. Tingkat kepuasan pasien terhadap masing-masing sub-variabel pada dimensi ketanggapan (no. 6-10) ditunjukkan pada Gambar 2. 


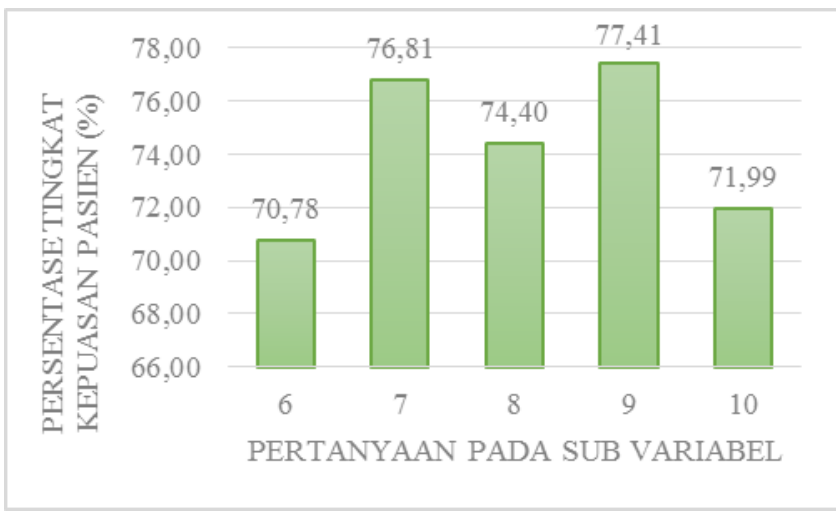

Gambar 2. Tingkat Kepuasan dari Sub Variabel

Dimensi Ketanggapan

\section{Dimensi Kemampuan atau Assurance}

Apabila ditinjau dari dimensi kemampuan, sebagian besar pasien (65\%) yang berkunjung ke Puskesmas Tlogosadang menyatakan kurang puas. Sebaliknya, sebanyak $31 \%$ dan $4 \%$ pasien berturutturut tergolong di dalam kategori puas dan sangat puas. Hal ini dikarenakan pasien merasa bahwa petugas kurang mampu memberikan informasi obat yang dapat dipertanggung jawabkan. Selain itu, responden juga merasa kurang puas terhadap kemampuan petugas dalam menyampaikan penjelasan KIE obat meskipun respon yang diberikan cepat. Tingkat kepuasan terhadap dimensi kemampuan, ditinjau dari jumlah pasien dapat dilihat pada Tabel 5. Selain itu, teramati bahwa nilai rata-rata tingkat kepuasan pasien terhadap masingmasing sub-variabel pada dimensi kemampuan adalah 50,84\% merasa kurang puas, seperti ditunjukkan pada Gambar 3.

Menurut Azwar dalam Murtiana, dkk. (2016) kepuasan yang dirasakan oleh seseorang sangat bervariasi untuk dimensi kemampuan yang mengacu pada kode etik profesi, seperti relationship, kenyamanan pelayanan atau amenities, pengetahuan dan kompetensi teknik atau scientific knowledge and technical skill, dan keamanan tindakan atau safety.
Dalam hal ini, petugas kefarmasian dinilai masih kurang dalam hal kemampuan technical skill yang mungkin menjadi penyebab rasa kekurangpuasan pasien terhadap pelayanan petugas dalam memberikan jaminan atas kebenaran informasi yang diberikan.

Tabel 5. Tingkat Kepuasan Pasien Terhadap Dimensi Kemampuan Ditinjau dari Jumlah Pasien.

\begin{tabular}{clcc}
\hline No & $\begin{array}{c}\text { Tingkat } \\
\text { Kepuasan }\end{array}$ & $\begin{array}{c}\text { Jumlah } \\
\text { Responden }\end{array}$ & $\begin{array}{c}\text { Presentase } \\
\text { Responden } \\
(\%)\end{array}$ \\
\hline 1 & Sangat Puas & 3 & 4 \\
2 & Puas & 26 & 31 \\
3 & Kurang Puas & 54 & 65 \\
4 & Tidak Puas & 0 & 0 \\
\hline
\end{tabular}

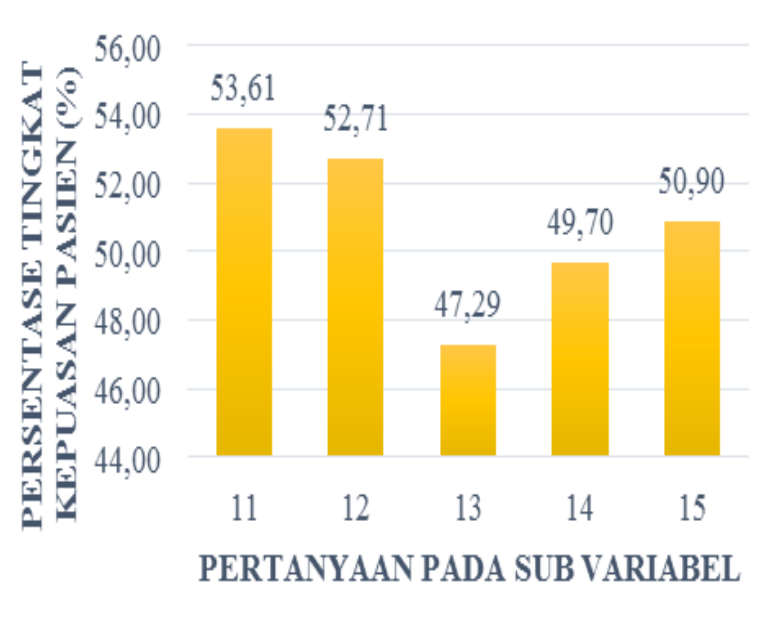

Gambar 3. Tingkat Kepuasan dari Sub

Variabel Dimensi Kemampuan

\section{Dimensi Bukti Fisik Atau Tangibility}

Tingkat kepuasan terhadap dimensi bukti fisik (Tabel 6) menunjukkan bahwa $57 \%$ pasien menyatakan kurang puas, $35 \%$ pasien menyatakan puas, sedangkan hanya $8 \%$ pasien merasa sangat puas. Hal ini mungkin disebabkan oleh beberapa faktor berikut ini: 
1. Fasilitas ruang tunggu yang kurang memadai. Pasien kekurangan tempat duduk sehingga harus berdiri selama menunggu proses pengambilan obat;

2. Kebersihan ruang tunggu yang kurang baik. Frekuensi pembersihan ruangan oleh pihak cleaning service tidak dilakukan setiap jam serta sikap kesadaran yang rendah dari para pengunjung untuk membuang sampah pada tempat yang telah disediakan;

3. Tidak tersedianya ruangan khusus untuk pelayanan informasi obat. Ruangan khusus ini sangat diperlukan untuk memberikan keleluasaan kepada petugas instalasi farmasi dalam memberikan informasi mengenai obat kepada pasien.

Tabel 6. Tingkat Kepuasan Pasien terhadap Dimensi Bukti Fisik Ditinjau dari Jumlah Pasien.

Di sisi lain, tingkat kepuasan pasien terhadap

\begin{tabular}{clcc}
\hline No & $\begin{array}{c}\text { Tingkat } \\
\text { Kepuasan }\end{array}$ & $\begin{array}{c}\text { Jumlah } \\
\text { Responden }\end{array}$ & $\begin{array}{c}\text { Presentase } \\
\text { Responden } \\
(\%)\end{array}$ \\
\hline 1 & Sangat Puas & 7 & 8 \\
2 & Puas & 29 & 35 \\
3 & Kurang Puas & 47 & 57 \\
4 & Tidak Puas & 0 & 0 \\
\hline & Jumlah & 83 & 100
\end{tabular}

masing-masing sub-variabel pada dimensi bukti fisik menghasilkan nilai rata-rata $52,83 \%$ merasa puas. Secara keseluruhan kepuasan tersebut disebabkan oleh kerapian dari Puskesmas Tlogosadang, yang sangat baik dan tertata. Selain itu, pihak puskesmas juga melengkapi kenyamanan pasien, dengan menyediakan brosur tentang informasi obat sehingga pasien dapat memperoleh informasi obat yang dibeli secara umum. Hasil pengamatan tersebut ditunjukkan pada Gambar 4.

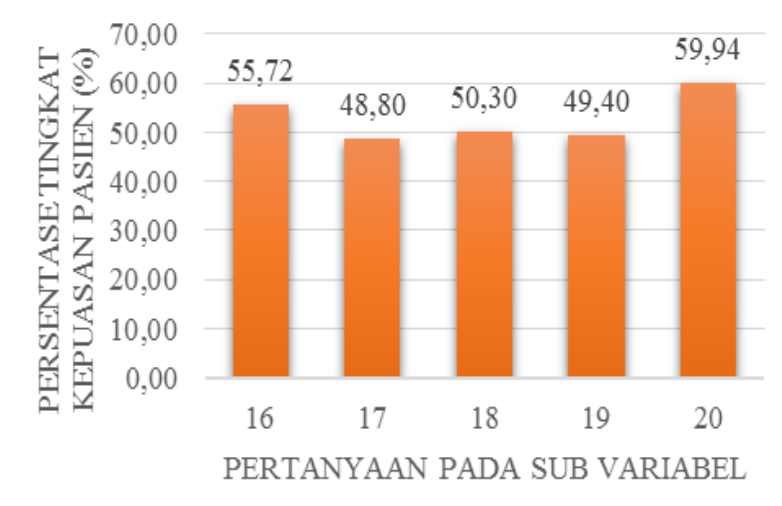

Gambar 4. Tingkat kepuasan terhadap masingmasing sub-variabel pada dimensi bukti fisik

\section{Dimensi Empati atau Emphaty}

Hasil pengukuran terhadap tingkat kepuasan pasien pada dimensi empati ditunjukkan pada Tabel 7. Sebanyak $60 \%$ pasien menyatakan puas terhadap pelayanan kefarmasian di Puskesmas Tlogosadang. Hal ini berkaitan dengan keramahan petugas pada saat memberikan pelayanan, tidak membeda-bedakan pasien, dan menerima setiap pertanyaan yang disampaikan oleh pasien.

Berdasarkan pengukuran terhadap tingkat kepuasan pasien pada dimensi empati, dijumpai nilai rata-rata $76,93 \%$ pasien yang tergolong di dalam kategori sangat puas. Hal ini dikarenakan petugas memberikan perhatian yang tidak membedakan pasien serta kesungguhan petugas dalam memberikan informasi obat. Menurut Notoadmodjo dalam Murtiana, dkk. (2016), salah satu faktor yang mempengaruhi kepuasan pasien yaitu empati yang diberikan oleh petugas pelayanan kesehatan. Sikap ini akan menyentuh 
emosi dari pasien, sebagai faktor yang mempengaruhi tingkat kepatuhan pasien.

Tabel 7. Tingkat Kepuasan Pasien terhadap Dimensi Empati Ditinjau dari Jumlah Pasien.

\begin{tabular}{clcc}
\hline No & $\begin{array}{c}\text { Tingkat } \\
\text { Kepuasan }\end{array}$ & $\begin{array}{c}\text { Jumlah } \\
\text { Responde } \\
\text { n }\end{array}$ & $\begin{array}{c}\text { Presentase } \\
\text { Responden } \\
(\%)\end{array}$ \\
\hline 1 & Sangat Puas & 33 & 40 \\
2 & Puas & 50 & 60 \\
3 & Kurang Puas & 0 & 0 \\
4 & Tidak Puas & 0 & 0 \\
\hline & Jumlah & 83 & 100 \\
\hline
\end{tabular}

\section{Tingkat Kepuasan Berdasarkan Lima Dimensi}

Pengukuran tingkat kepuasan pasien di Puskesmas Tlogosadang Lamongan dilakukan dengan menggunakan 5 dimensi. Secara umum nilai rata-rata dari hasil analisis terhadap 5 dimensi tersebut adalah $66,27 \%$ tergolong di dalam kategori puas. Hal ini menunjukkan bahwa puskesmas telah memberikan pelayanan dengan baik kepada pasien rawat jalan BPJS sebagai wujud perasaan pasien yang timbul dari kinerja layanan kesehatan yang didapatkannya

Tabel 8. Pengukuran Tingkat Kepuasan dari 5

Dimensi

\begin{tabular}{clc}
\hline No & \multicolumn{1}{c}{ Dimensi } & $\begin{array}{c}\text { Persentase } \\
\text { kepuasan (\%) }\end{array}$ \\
\hline 1 & Kehandalan & 76,45 \\
2 & Ketanggapan & 74,28 \\
3 & Kemampuan & 50,84 \\
4 & Bukti Fisik & 52,83 \\
5 & Empati & 76,93 \\
\hline & Rata-rata & 66,27 \\
\hline
\end{tabular}

\section{KESIMPULAN}

Dapat disimpulkan bahwa tingkat kepuasan pasien terhadap 5 dimensi adalah sebanyak $66,27 \%$ pasien rawat jalan BPJS merasa puas dengan pelayanan di Instalasi Farmasi Puskesmas Tlogosadang.

\section{UCAPAN TERIMAKASIH}

Penulis mengucapkan terimakasih kepada Universitas Muhammadiyah Gresik dan Puskesmas Tlogosadang Lamongan serta semua pihak yang telah membantu terlaksananya penelitian. Kami berharap hasil penelitian ini mampu memeberikan wawasan pada pembaca.

\section{DAFTAR PUSTAKA}

Eninurkhayatun, B., Suryoputro, A., Fatmasari, E.Y. 2017. Analisis Tingkat Kepuasan Pasien terhadap Kualitas Pelayanan Rawat Jalan di Puskesmas Duren dan Puskesmas Bergas Kabupaten Semarang Tahun 2017. Jurnal Kesehatan Masyarakat. Vol. 5 No. 4 Hlm. 33-42.

Kotler, A. 2004. Dasar-Dasar Pemasaran, Edisi Kesembilan. Jakarta: Gramedia.

Menkes RI. 2016. Peraturan Menteri Kesehatan Republik Indonesia Nomor 74 Tahun 2016 tentang Standart Pelayanan Kefarmasian di Puskesmas. Jakarta.

Murtiana, E., Majid, R., Jufri, N.N. 2016. Hubungan Mutu Pelayanan Kesehatan kepada Kepuasan Pasien BPJS di RSUD Kota Kendari Tahun 2016. Jurnal Ilimiah Kesehatan Masyarakat. Vol. 1 No. 4.

Ndjurumbaha, T. 2015. Analisis Tingkat Kepuasan Masyarakat atas Kualitas Pelayanan di Puskesmas Waingapu Kabupaten Sumba Timur. Tesis. Universitas Terbuka Jakarta.

Novaryatiin, S, dkk. 2018. The Level of Patient Satisfaction to Pharmaceutical Service in Dr. 
Yoga,dkk-Tingkat Kepuasan Pelayanan Pasien Rawat Jalan BOJS di Instalasi Farmasi Puskesmas Tlogosadang Kabupaten Lamongan-Vol 3 No 1-hlm 10-20

Murjani Hospital Sampit. Borneo Journal of Pharmacy, Vol. 1 Hlm. 22-26.

Presiden RI, Peraturan Presiden Indonesia Nomor 82

Tahun 2018 tentang Jaminan Kesehatan. Jakarta.

Sondari, A. 2015. Analisis Kepuasan Pasien Rawat Jalan Peserta Jaminan Kesehatan Nasional (JKN) di Rumah Sakit Umum Daerah (RSUD) Kabupaten Brebes Tahun 2015. Skripsi. Fakultas Ilmu Keolahragaan. Universitas Negri Semarang. Semarang.

Sugiyono 2017. Metode Penelitian Kuantitatif, Kualitatif, dan R\&D. Bandung: CV. Alfabet.

Sunarto 2011. Analisis Tingkat Kepuasan dan Harapan Pasien terhadap Pelayanan Puskesmas dan Rumah Sakit Daerah Propinsi DIY. Jurnal Kesehatan Masyarakat. Vol. 5 No. 1 Hlm. 2835. 
